\section{Caladium Height Control with Paclobutrazol Drench Applications}

\author{
James E. Barrett, Carolyn A. Bartuska, and Terril A. Nell \\ Environmental Horticulture Department, University of Florida, Gainesville, \\ FL 32611
}

Additional index words. Caladium $\times$ hortulanum, growth regulators

\begin{abstract}
Paclobutrazol drench treatments were evaluated for efficacy on Caladium $\times$ hortulanum (Birdsey) cultivars Aaron, White Christmas, and Carolyn Wharton. Drenches at $2.0 \mathrm{mg} / \mathrm{pot}$ did not reduce height of 'Aaron' and 'White Christmas' plants when applied 1 week after planting, but $2.0 \mathrm{mg}$ applied at 3 weeks after planting did result in shorter plants. The difference for time of application may be due to the amount of roots present to take up paclobutrazol when applied. In two factorial experiments, there were no interactions between cultivar and time of application or amount of chemical. Paclobutrazol at $0.5 \mathrm{mg} /$ pot resulted in plants that were shorter than the controls. Higher amounts of paclobutrazol provided additional reductions in height, but there was variation between the experiments for degree of effect with amounts $>1 \mathrm{mg}$. Generally, commercially acceptable height control was provided by paclobutrazol drench treatments at 0.5 and 1.0 $\mathrm{mg} /$ pot applied 3 weeks after planting. Chemical names used: (2RS,3RS)-1-(4-chlorophenyl)4,4-dimethyl-2-1,2,4-triazol-1-yl-pentan-3-ol (paclobutrazol).
\end{abstract}

Caladiums are frequently produced in containers to be used as interior plants or transplanted to landscape beds. Plant height for caladium cultivars varies greatly (Wilfret and Hurner, 1982), and growers report that height control with butanedioic acid mono(2,2-dimethylhydrazide) (daminozide) or 2chloroethyltrimethylammonium chloride (chlormequate chloride) sprays has been unsuccessful. Thus, some of the more attractive larger cultivars are difficult to produce. Also, to avoid excessive size, growers frequently market potted caladiums before they are adequately developed.

Paclobutrazol provides height control of several floriculture crops (Barrett and Nell, 1989; Shanks, 1980). It is active when applied to the growing medium but has little efficacy when applied to leaves because it is not translocated out of leaves (Barrett and Bartuska, 1982; Davis et al., 1988). The only aboveground organs in caladiums are leaves, which indicates that paclobutrazol sprays would have little efficacy. In preliminary trials, paclobutrazol sprays reduced caladium height only when applied frequently and directed at the base of the plant, which provided some drench effect and coverage of leaves as they emerged from the medium. Paclobutrazol drenches produce good height control on various container-grown floriculture crops (Barrett and Nell, 1994); therefore, the current study evaluated efficacy of paclobutrazol drench treatments for height control of 'Aaron', 'White Christmas', and

Received for publication 28 June 1994. Accepted for publication 14 Jan. 1995. Florida Agriculture Journal Series no. R-02982. This research was supported by Uniroyal Chemical Co. and Bytes, Sons and Daughters. The cost of publishing this paper was defrayed in part by the payment of page charges. Under postal regulations, this paper therefore must be hereby marked advertisement solely to indicate this fact.
'Carolyn Wharton' caladiums, three of the taller cultivars grown as potted plants (Wilfret and Hurner, 1982).

\section{Materials and Methods}

Size one caladium tubers $(>3.8$ and $<6.4$ $\mathrm{cm}$ in diameter) were obtained from a commercial propagator at the beginning of each experiment. Tubers were de-eyed (removal of terminal section of buds) and planted three per 1.5 -liter $(15 \mathrm{~cm})$ pot in Vergro Klay Mix $-4.45(\mathrm{x})+0.70114\left(\mathrm{x}^{2}\right) ; r^{2}=0.38$.
(Verlite Co., Tampa, Fla.). This medium does not contain pine bark, which can reduce the efficacy of paclobutrazol (Barrett, 1982). Nitrogen was applied at each irrigation at 150 mg.liter ${ }^{-1}$ from a $20 \mathrm{~N}-4.4 \mathrm{P}-16.6 \mathrm{~K}$ liquid fertilizer. In Expts. 1 and 3, minimum night and maximum day temperatures were $18 / 32 \mathrm{C}$; in Expt. 2, they were 18/27C.

Drenches were applied using $120 \mathrm{ml} /$ pot. Height from pot rim to top of the foliage was measured in each experiment. Statistical analyses included analysis of variance, regression analysis, and Tukey's honestly significant difference test.

Time of application (Expt. 1). 'Aaron' and 'White Christmas' caladium tubers, planted on 2 May 1991, were used in separate experiments. Paclobutrazol at $2.0 \mathrm{mg} /$ pot was applied as a drench 1 week or 3 weeks after planting, and nontreated control plants were included. The design for each cultivar was a randomized complete block, with three replications and two pots per experimental unit. Data were recorded on 30 May.

Paclobutrazol amounts (Expt. 2). Cala-

Table 1. Effect of paclobutrazol on 'White Christmas' and 'Aaron' caladium height (Expt. 1).

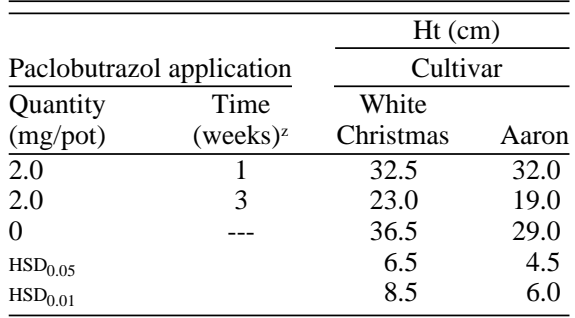

${ }^{2}$ Number of weeks after planting.

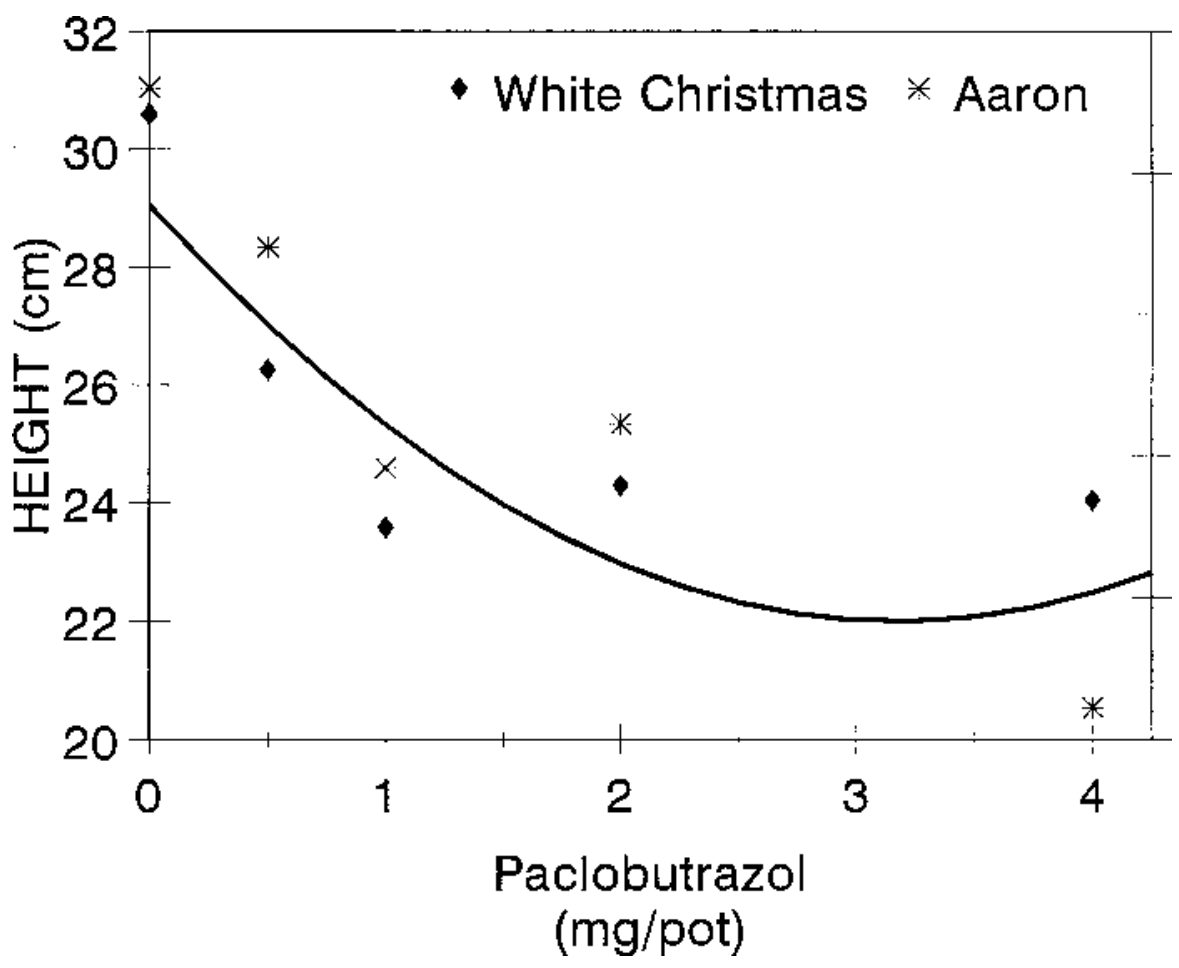

Fig. 1. Effect of paclobutrazol on height control of 'White Christmas' and 'Carolyn Wharton' caladium (Expt. 2). Cultivar $\times$ rate interaction was nonsignificant at $P>0.05$. Data pooled over cultivar. $\mathrm{y}=29.07$ 
dium tubers were planted 26 Feb. 1992. A two $\times$ five factorial arrangement was used to study two cultivars ('Carolyn Wharton' and 'White Christmas') and five paclobutrazol drench levels $(0,0.5,1.0,2.0$, or $4.0 \mathrm{mg} / \mathrm{pot})$. Treatments were applied 3 weeks after planting, and data were recorded on $28 \mathrm{Apr}$. The experiment was a randomized complete block with four replications and three pots per experimental unit.

Time and amount (Expt. 3). Caladium tubers were planted 7 May 1992. A factorial experiment was imposed using two cultivars ('Carolyn Wharton' and 'White Christmas'), three application times $(1,2$, and 3 weeks after planting), and three paclobutrazol drench amounts $(0.5,1.0$, and $2.0 \mathrm{mg} / \mathrm{pot})$. A nontreated control was included for each cultivar but was not included in factorial analysis. The experiment was in a split-plot design with five replications and two plants per experimental unit. Main plots were cultivars and subplots were application time and paclobutrazol amount. Data were recorded on 11 June.

\section{Results and Discussion}

Paclobutrazol drench applications (2 mg/ pot) at week 1 had little effect on plant height in Expt. 1; however, for both cultivars, application at 3 weeks after planting resulted in plants shorter than those in control and week 1 treatments (Table 1). In Expt. 2, the cultivar $\times$ paclobutrazol amount interaction and the cultivar effect were not significant. There was a significant quadratic relationship between paclobutrazol amount and plant height (Fig. 1). Height decreased as amount increased to up to $1 \mathrm{mg} /$ pot; additional paclobutrazol had less effect on height.

The three- and two-way interactions and cultivar differences were not significant in Expt. 3 (Table 2), but the main effects of time of application and amount were significant. Plants were shorter when drenches were applied 3 weeks after planting than at 1 or 2 weeks. There was a linear rate effect with increasing amounts of paclobutrazol providing additional height reduction. Also, contrast comparison of nontreated control vs. paclobutrazol drench amounts was significant at $P>0.0001$.

These results demonstrate the efficacy of paclobutrazol drench applications for cala- dium height control and support results from a previous report with a single caladium experiment (Barrett and Nell, 1994). Caladiums are highly variable between plants within a planting and from year to year, and this variability is evident in these experiments. In Expt. 1, there was a relatively large difference in response to paclobutrazol at week 1 and week 3 , whereas in Expt. 3, there was only a small difference that would not be commercially important. Also, in Expt. 2, paclobutrazol amounts $>1 \mathrm{mg} /$ pot did not produce incremental reductions in height, but in Expt 3, plants receiving $2 \mathrm{mg}$ were considerably shorter than those treated with $1 \mathrm{mg}$.

Paclobutrazol had more activity with later applications in Expt. 1 and to a lesser extent in Expt. 3. Caladium tubers do not have roots when planted, and few roots developed by 1 week. However, by 3 weeks after planting, leaves were emerging rapidly, and there was much greater root growth. For drench applications of height-control chemicals to containergrown crops, the relative importance of quick uptake of the chemical soon after the solution is applied compared to slow uptake by the plant over time as the roots expand into new regions of the growing media has not been established. These results, where application after roots were present had greater activity, indicate that uptake soon after application is most important in caladiums.

There are no universal commercial standards for optimum height for potted caladiums; amount of desired height control varies with individual grower preferences. Generally, plant heights of 25 to $28 \mathrm{~cm}$ would be acceptable and resulted from paclobutrazol drenches of 0.5 or $1.0 \mathrm{mg} /$ pot. These concentrations did not cause malformed leaves, which were observed with higher concentrations that produced shorter plants. For commercial use, recommendations for paclobutrazol applications to be made at $\approx 3$ weeks would avoid the potential for reduced efficacy from treatments applied too early.

\section{Literature Cited}

Barrett, J.E. 1982. Chrysanthemum height control by ancymidol, PP333, and EL-500 dependent on medium composition. HortScience 17:896-897. Barrett, J.E. and C.A. Bartuska. 1982. PP333 effects
Table 2. Time of treatment and concentration (concn) of paclobutrazol drench affect height of 'White Christmas' and 'Carolyn Wharton' caladium (Expt. 3).

\begin{tabular}{|c|c|c|}
\hline Main effects ${ }^{2}$ & & $\mathrm{Ht}(\mathrm{cm})$ \\
\hline \multicolumn{3}{|l|}{ Time of treatment (week) } \\
\hline 1 & & 26.5 \\
\hline 2 & & 26.5 \\
\hline 3 & & 25.0 \\
\hline Linear & & 0.05 \\
\hline Quadratic & & NS \\
\hline \multicolumn{3}{|l|}{ Paclobutrazol (mg/pot $)^{x}$} \\
\hline 0.5 & & 28.0 \\
\hline 1.0 & & 27.0 \\
\hline 2.0 & & 23.5 \\
\hline Linear & & 0.0001 \\
\hline Quadratic & & 0.0340 \\
\hline Source & $P>\mathrm{F}$ & \\
\hline Cultivar & $\overline{N S}$ & \\
\hline Time of treatment & 0.0032 & \\
\hline Concn & 0.0001 & \\
\hline Cultivar $\times$ time & NS & \\
\hline Cultivar $\times$ concn & NS & \\
\hline Time $\times$ concn & NS & \\
\hline Cultivar $\times$ time $\times$ concn & NS & \\
\hline
\end{tabular}

${ }^{2}$ Data pooled over cultivar and paclobutrazol drench concentration for effect of time of treatment and pooled over cultivar and time of treatment for effect of paclobutrazol drench concentration.

${ }^{y}$ Number of weeks after planting.

${ }^{\mathrm{x}}$ Contrast comparison of nontreated control vs. paclobutrazol drench rates was significant at $P>\mathrm{F}$ 0.0001 .

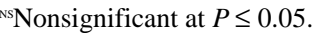

on stem elongation dependent on site of application. HortScience 17:737-738.

Barrett, J.E. and T.A. Nell. 1989. Comparison of paclobutrazol and uniconazole on floriculture crops. Acta Hort. 251:275-280.

Barrett, J.E. and T.A. Nell. 1994. Comparison of paclobutrazol drench and spike applications for height control of potted floriculture crops. HortScience 29:180-182.

Davis, T.D., F.L. Steffons, and N. Sankhla. 1988 Triazole plant growth regulators, p. 63-105. In: J. Janick (ed.). Horticulture review. vol 10. Timber Press, Portland, Ore.

Shanks, J.B. 1980. Chemical dwarfing of several ornamental greenhouse crops with PP333. Proc. Plant Growth Regulat. Working Group 7:4651.

Wilfret, G.J. and G.T. Hurner. 1982. A survey of caladium cultivars grown in Florida and their characteristics as potted plants. Proc. Fla. State Hort. Soc. 95:190-194. 